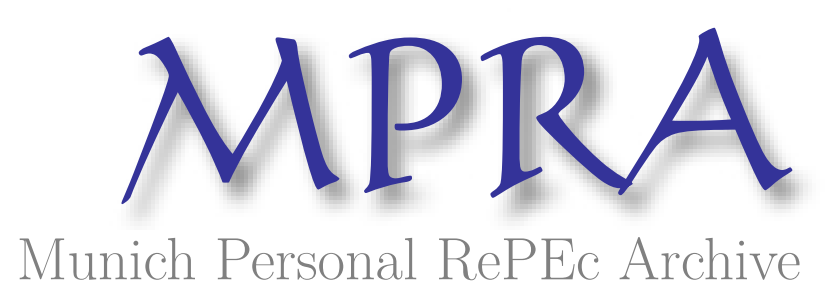

\title{
Measurment of Service Orientation of an Insurance Company in a Transitional Market
}

\author{
Pureta, Igor \\ Durham University
}

2001

Online at https://mpra.ub.uni-muenchen.de/89241/

MPRA Paper No. 89241, posted 28 Sep 2018 20:19 UTC 


\title{
MEASUREMENT OF
}

\section{SERVICE ORIENTATION OF AN}

\author{
INSURANCE COMPANY
}

IN A TRANSITIONAL MARKET

\section{IGOR PURETA}

The dissertation is submitted as a part of the requirement for the Degree of Master of Business Administration of Durham University in 2001 


\section{INTRODUCTION}

\section{Service quality - making the difference and giving impetus to the progress of a service company}

Service is an intangible product; one cannot see it or touch it. In fact, a service product does not even exist when it is bought. If one takes a holiday one cannot be sure how satisfied she or he will be until she or he returns home. First one has to order, very often to pay for it, and then one gets it. Contacting customers during holidays differs in many ways, depending on who is making the contact, on what occasion, and so on. Very often the service is a process that involves customers as co-producers. In most cases one buys a service without touching, tasting, feeling, smelling, or seeing it. Some services do not even have a defined price - usually a sales representative has to calculate it several times and recalculate it after the work is done. These circumstances make it difficult for consumers to evaluate services before purchasing them.

After a service has been purchased it is hard to tell if and when it will fail as a product. In the world where manufacturers make products using well-tested and monitored processes which ensure consistent quality, service companies deliver their products through a series of acts that can rarely be turned into a reliable routine process. Since the degree and the style of customer's participation vary, the control of service quality is more difficult than that of goods. An even greater disadvantage of the service in comparison with tangible products is that a customer usually takes service failure personally. These are the circumstances that make the customer feel uncertain and reserved when purchasing a service. 
On the other hand one can ask - how products distinguish from one another? The answer is - through service. Service, as an added value, distinguishes any product, be it tangible or intangible, from other similar products. The quality of service as an added value has a great impact on customers, their satisfaction with the company and the service as a product provided by that company.

Many companies have intuitively recognized that better service leads to improved financial success and have committed resources to improve service quality without assurances that it will pay off. Studies show 'that companies offering superior service achieve higher than normal market share growth, that the mechanisms by which service quality influences profits include increased market share and premium prices and that businesses in top quintile of relative service quality on average realize an $8 \%$ higher price than their competitors' (Zeithaml et al, 1996).

\section{Insurance company as a service organization}

Delivering high-quality service is considered an essential strategy for success and survival in today's competitive surroundings. Insurance companies are an inevitable segment of every economical system. The former insurance markets of the Central and Eastern European countries were mainly featured by a small number of state-owned insurance companies, lack of customer orientation towards voluntary insurance due to low living standards, insufficient level of information about insurance benefits, and bad experience with claim settlement which was time-consuming and value-consuming due to inflation.

Those companies were facing a whole range of difficulties partly inherited from command economy, but partly also as result of crises occurring during transition to market economy. De-monopolisation has resulted in privatisation of the former state-owned companies and in the growing number of new companies, often boosted by foreign capital. At the initial stage of the development of insurance service in the transitional countries the emphasis was on non-life insurance, that is, mostly on insurance against car-accident liability. 
Although a big impetus for the development of insurance, especially of life insurance, is expected from

- Legislation, i.e. conformation of regulations with the insurance practice in the European Union,

- $\quad$ Stimulating taxation policies for individuals as well as for employers,

- Completion of the privatisation of the state-owned monopolized insurance companies, and

- Diminished government influence on pension funds, insurance companies should work on the innovation and development of their services, especially those in the sphere of life insurance. They should come closer to prospective users through better information flow, various promotional activities, and the development of insurance agent network, as well as through the development of one's own organization, that is through investment in human resources, reduction of operating costs, and cheaper services - these are the ever more important prerequisites for the survival of insurance organizations on the market.

An insurance company as a service provider has to think not only about distinctive characteristics of service products, invisibility and intangibility, but also about the exceptional sensitivity of service customers: their fears, their limited time, and important constrains and needs.

This particularly refers to companies that sell services such as insurance. An insurance company sells a policy, that is, assurance that money will arrive at one point in the future that has been agreed in advance. To gain confidence, an insurance company must persuade the customer that it is the right company to trust to and it does it through "value added service". It has to persuade the customer that the company's priority is good communication with the customer, starting from the first contact when information is given to the point when the claim is being settled. If the contact as a value added service is not able to impart the sense of confidence to the customer, she or he will decide not to buy the product of the company, that is, a service that is based on trust and confidence. Furthermore, the customer with negative experience can influence many more potential customers not to give trust to an insurance company. To acquire confidence of the 
customers, an insurance company must give its best to convince them that it really deserves it. This is achieved by making the customer aware of the usefulness of the service. Only when the customer sees its use can she or he judge its quality, and it is the crucial point for the long-term progress of an insurance company.

But how does one know whether a company delivers quality service or not? How does one know whether a company is organized well enough to deliver high-quality service or not? These are the questions that I will try to answer in this dissertation.

The organization described in this paper is the daughter of an insurance company that has existed on the market of the country of origin for over 170 years. The mother company, deals primarily with property insurance.

The daughter company (further in the text: the Company) was founded in 1993 pursuant to the legal regulations of the Republic of Croatia, and although it was intended to be the copy of the mother company and primarily to deal with property insurance, the Serbian/Yugoslav aggression in Croatia did not allow such development.

The priority was given to the development of life insurance. Most contracts were concluded in co-operation with mediator agencies, but considerable attention was also given to the development of the Company's sales network.

Although transition countries show a tendency of growth in insurance services, the insurance in Croatia, and especially life insurance, is underdeveloped. The reasons lie in low income per capita, growing unemployment (25\% in the year 2000), low living standard, reduced savings potential of the population, and state-owned pension fund that used to work on the pay-as-you-go principle.

An important influence on life insurance is also the demographic trend in the country. Namely, the number of people of over 60 years of age is growing, causing a disproportion between the working and the retired population (at the moment it is 1:1). This imposes a heavy burden on the pension fund. An additional burden to the fund is a large number of prematurely retired people as the consequence of the transition crisis. Croatia intends to introduce the so called three-pillar pension fund model, which is expected to encourage the growth of life insurances, but the government keeps postponing its implementation. 
The Company grew very quickly and from its establishment to 1999 it achieved results that have placed it on top of the life insurance market according to collected premiums. This sudden post-war growth can be thanked to an early penetration of the market and to the fact that the former state-owned companies could not adjust to new business circumstances.

In spite of success, the sudden growth brought some disadvantages as well. The development of the service organization could not follow the market success; an increasing number of contracts and employees was not receiving support from the existing or new services. The Company was very slow to develop those support services, as the market influences were static; the old ways of doing business seemed to work "just fine". The Company's primary distribution channel has been the agent (be it an employee, an agency, or a freelance).

The data processing system is a billing mechanism. It stores very limited customer information. By rejecting the notion of a database as a basic marketing engine the Company became inefficient. It embraced the decades old marketing models and refused to approach the market in a 'smart way'. The focus was on the quantity of leads, shortterm relationships with customers and to a minor degree on a limited mail order distribution of low-cost services such as child insurance.

In order to prevent a decline in sales, increased expenses, and melting profits, the Company accepted the changes as necessary. The policyholder of today is rather sophisticated and does not decide to buy insurance just on the basis of price, but also on quality of information, handiness, flexibility, and first of all, on service quality. These demands, as well as the arrival of competition, forced the Company to speed up the analysis of its own approaches and methods of keeping the policyholder satisfied.

These efforts and the communication with either the customer or the employee were uncoordinated and inconsistent, which created a confusing image of the Company. The used techniques did not live up to challenges and the possibilities of the 90s; issues like 
privacy, targeting techniques, and customer information management were not discussed. A company has to think well in advance if it wants to keep its competitive edge.

One of the ways to improve the quality and quantity of business is to maintain and assure the satisfaction of customers - policyholders. Many would agree that a well-performed service is a key factor for the achievement of market success. A company has to provide better service than the customer would expect. That is how the company makes sure that it is noticed by the customer, and recommended to friends and relatives who want more of the service.

For these reasons a company needs a different focus, which primarily presumes complete understanding and acceptance of the actual state of development of support services. In order not to stay behind or lose pace on the ever-changing market, a company should be sensible enough to implement different marketing strategies (extending the range of products, exercising the most attractive ways of promotion, price cutting, increasing the number of outlets, and updating the image of the company). It should try to devise a system that would not only produce reliable leads for the agents or increased level of awareness generated by advertising and direct mail, but would also raise the level of service quality. The central issue in the transition to a new, customer-oriented approach is keeping the client satisfied.

This paper will investigate how service orientation can be developed in an insurance company. It starts from the employees' perspective to identify the areas that need improvement leading to enhance customer's service experience. 


\section{Objectives of the study}

The objectives of this study were:

1. to understand the importance of service orientation

Various studies indicate that important organizational outcomes such as, profit, growth, customer satisfaction, and loyalty result directly from organizational service orientation. The understanding of the importance of service orientation and its development within a Company should help to clarify the possibilities to improve its market position. If a company is able to identify and understand its service orientation, it will also be able to influence the outcomes of its work. A lack of understanding of service orientation may inhibit successful organizational competitive performance.

2. to measure organizational service orientation of an insurance company in Croatia (from the employees' perspective)

Under the term of service orientation Lytle et al., (1998) are describing "service events, practices, and procedures within a work setting that expect and reward service excellence". The ability to measure service orientation of the Company will make possible the comparison of the Company's outcomes with the results of service orientation measurement. In this paper I wish to establish whether the Company is perceived as service-oriented by its employees. The investigation will find out whether the Company's service organization and the delivery of service distinguish it from the competition. If the employees' perceptions of events, practices, and procedures, as well as of the rewarded, supported, and expected behaviour constitutes the working climate in the company that fosters high-quality service to customers, then one can expect that this will be distinguishing feature of such organization from others. 
3. to verify whether employees differ in perception of the Company as a service organization with respect to sex, department, hierarchy, and regional office

Service orientation depends on individuals and literature suggests that service-oriented people are "helpful, thoughtful, considerate and cooperative" (Lytle et al, 1998). Service orientation of a company is the results of individual effort and can be observed through behaviour. Those efforts and the behaviour of each individual directly influence the nature and the quality of service organization within the company. My intention is to see whether the employees differ in perception of several distinctive factors. 


\title{
THEORETICAL VIEWS ON SERVICE QUALITY
}

\author{
Improving the quality of the external customer service \\ experience
}

Until recently, and in many companies this is still the case, the main focus of every industry was the product. The emphasis was primarily put on raw materials. Later the focus shifted to sales, i.e. to the market domination and utilization of distribution network. After a period of an even orientation toward, both, products and sales, production and distribution, the time has come for a new orientation - satisfaction of the customer. The reasons for such development lie in the previous phase; production and distribution made products or services available to the customers more than ever. The struggle for market shares started intense search for new ways to attract and retain the customer. Customers have realized that they can get a better service if they want it. That turned the buyer into a demanding customer, who is more mature and harder to please and who wants to get value for his money.

\section{Customer satisfaction}

Offering value greater than that of competitors is the key to success in today's competitive markets. The satisfaction of the customer depends on perceived service performance and how it meets his expectations. True quality lies in the way the customer sees the service and this is what a company has to adjust to. The customer is satisfied only when a product completely meets or exceeds his needs and expectations. Expectations are formed through post-buying experiences, discussion with other people and suppliers' marketing activities. 
Customer satisfaction is mostly based on the perception of the service quality that is one of the most researched areas of services marketing. The service quality awareness was raised simultaneously with the focus on production quality, total quality management, and overall customer satisfaction.

Earlier studies of service quality were based on customer satisfaction theory developed in Europe. Its origins can be traced back to the early eighties of the $20^{\text {th }}$ century induced by changes in economy and growing needs of management. Those needs opened communication between practitioners and researchers, which led to literature that had basis in everyday managerial issues. The literature was interdisciplinary and covered different areas such as operations or human resources management. Management academics regularly attended services marketing conferences and their work considerably influenced the development of services marketing thinking. Another positive influence on such thinking was the broad international base of writers and researchers (Brown et al, 1994).

In that early phase of development of services marketing the Harvard Business Review published an article by Takeuchi and Quelch (1983) on service quality. Additional articles followed in the Journal of Marketing where A. Parasuraman, Valerie Zeithaml, and Leonard Berry published the article "A Conceptual Model of Service Quality and Its Implications for Future Research" (1985). In the article, the authors proposed their Gaps Model of service quality and described an investigation of service quality in four businesses. That article and subsequent studies not only by Parasuraman and his team, but also by other authors put the service quality in the highlights of services marketing (Brown et al, 1994). 
The customer is able to assess service quality at the moment of interaction with the company. This interaction is termed 'service encounter'. Solomon et al. presented in 1985 the critical components of service encounters in article "A Role Theory Perspective on Dyadic Interactions: The Service Encounter" published in the Journal of Marketing. They proposed that the "dyadic interaction between a service provider and a customer is an important determinant of the customer's overall satisfaction with a service." That work led to further investigations and helped to establish the service encounter as a practical research topic (Brown et al, 1994).

The term 'service encounter' focuses on the interpersonal element of a company's service performance. It has been defined by Shostack (1985) as "a period of time during which a consumer directly interacts with a service." The definition covers all aspects of the service company with which the consumer may interact: personnel, physical facilities, and other visible elements. Shostack suggests that service encounters can occur even without any human interaction, although "a study of relationship marketing in the life insurance industry found clients' satisfaction with their contact person (or agent) to be significant predictor of overall satisfaction with the service" (Bitner et al, 1990).

From the customer's point of view that interaction is the service. Many situations showed that the front-line employees were not trained to understand customers or did not have the authority to serve customers in ways that ensured effective service. Front-line employees are often underpaid and under-trained which results in low motivation, dissatisfaction with the job, high turnover, and finally, dissatisfied customers.

Some service companies understand that the organization of the service encounter involves more "than training employees to say 'have a nice day' or to answer the phone on or before the third ring." Service encounter management must understand often complicated and "complex behaviours of employees that can distinguish a highly satisfactory service encounter from a dissatisfactory one, and than training, motivating and rewarding employees to exhibit those behaviours." (Bitner et al, 1990) 


\section{Relationship marketing}

As the importance of service grows, a company has to monitor closely its own capabilities and performance. It is necessary to focus on the improvement of the company's own approach to customer satisfaction and to the definition of the relationship between good service and financial success of the company. Awareness of the relationship between service quality and cost, profitability, customer satisfaction, customer retention, and positive word of mouth, has led to even more intensive research. Service quality has become widely recognized as a driver of corporate marketing and financial performance (Buttle F., 1996.). The tenet is that a happy and satisfied customer is a loyal customer. If the goal set so far was to get more customers, today's priority is to keep the existing ones, not only because it is much more cost-effective. A satisfied customer keeps coming back and stays loyal to the company, turning into an efficient witness of a certain product and of its effects. Relationship marketing recognizes the value of existing customers and the need to provide sustained services to the existing customers so that they remain loyal. Services researchers since the early 1980 s have drawn attention to the need to retain as well as attract customers.

The data obtained from the research of the European insurance market, carried out by various insurance companies, speak of customer satisfaction and the business results of the insurer.

- 100 satisfied policyholders bring 25 new ones

- For each received complaint, 20 other policy holders feel the same, but they are too lazy to complain

- The cost of attracting a new policyholder is 5 times higher than the cost of retaining the old one

- A satisfied policyholder will share his experience with 4-5 people and a dissatisfied one with $8-10 ; 13 \%$ of dissatisfied customers will tell 20 other people

- Negative word of mouth is considered to be twice as powerful as the positive 
- Companies with low service quality lose $2 \%$ of their market share a year, whereas companies with high service quality increase their market share $6 \%$ a year (European Insurance Bulletin, Winter 1997/1998)

These results undoubtedly suggest that insurance companies have to include service orientation in their strategies to be market successful.

For marketers this is a step away from traditional marketing approaches. Studies of customer retention definitely shifted the focus on such issues as "building an effective recovery strategy for service failure situations or offering service guarantees to reduce risk and build loyalty" (Brown et al, 1994).

Not until a certain number of years have passed does a policy bear profit. This fact makes the customer retention a critical element for the business. In the insurance industry a company that can boosts retention 5\%, can decrease the cost $25 \%$ (European Insurance Bulletin, Winter 1997/1998). Improving the quality of customer relationship through relationship marketing is not a cost; it is an investment in the future! If a company knows what the customer thinks, feels, and wants, it will meet the customer's needs better.

The company should be able to reinforce relationships by tapping the available information and by using personalized communications to get its messages across. The database and the relationship marketing strategy can help to increase retention and reduce the cost. An information-rich database has become a major goal of major insurance providers. Data such as date of birth, household members, marriages, new births, are needed to maximize the database potential. A company should be able to treat every customer as an individual, to identify the "right" people, communicate with customers in the "right" and relevant way, and by doing so increase the service quality and build the customer loyalty. A company should find out what its customers like and create personal profiles/datasets that include demographic, psychological, and relational characteristics of the customer. The services could then be offered through multi-line product penetration or cross-selling at the household level. 
The key to building customer relationship is communication: creating a dialogue between the customer and agent at the local level and between the customer and the company at the national level. Each event, "moments of truth" in the company jargon, gives both the company and the local field agent an opportunity to build loyalty.

\section{Internal marketing}

There is a tendency to focus service quality improvement on the front line. This, after all, is where the company delivers the service directly to the customer. This notion of service quality, however, limits its strategic use because service is not the sole responsibility of the front-line employees and the service strategy should not be limited to the end point of the service delivery process.

It is unreasonable to expect front-line employees to overcome the inefficiencies and errors of the support departments. Such attitude denies the benefits of improving efficiency throughout the company by introducing an effective management system. It is hard to steadily improve service quality and retain customers if an organization does not recognize the importance of personnel other than the front-line. All employees are important in this process and it is the task of all employees to satisfy the customer. Theoretical considerations of the concept started with what we today call internal marketing. Internal marketing has two basic premises. The first is that "everyone in the organization has a customer". It is not just front-line employees who need to be concerned with satisfying what we call the company's customers. Everyone in the organization has someone whom he or she must serve. Everyone has a customer - an internal customer and everyone is a service provider. The second premise is that internal customers must be happy with their jobs before they can serve the company's customer effectively. Such view of the company implies that "marketing tools and concepts (e.g. segmentation and marketing research) can be used internally with employees" (Brown et al, 1994). The basic premise of internal marketing is that satisfied employees (or well-served internal 
customers) will produce satisfied customers (or well-served external customers). George's 1990 review of internal marketing concluded that "Empowerment is highly relevant to internal marketing, and this topic has received solid and thought-provoking coverage in a recent services management publication" (Brown et al, 1994).

\section{Measuring service quality}

Although many studies dealt with different aspects of service quality, few tried to develop an empirical measurement model that would provide a tool for systematic approach to this issue.

Companies have various ways of appraising their service quality. Such appraisals are considered the key components of the general management system. By appraising performance in an area such as service providing, a company is able to measure its own progress with respect to general goals, and it can continually improve the performance and the application of its business strategy. Companies can use the performance appraisal system as an additional assurance that the strategy will be carried out successfully and thoroughly. A simple appraisal of performance, as opposed to the traditional financial indicators, means a new approach for many organizations and a very important step forward.

Customers should take the central place in defining the strategy, and performance appraisal should not be based purely on short-term income figures. The aim is to gain long-term customers. And long-term customers mean free advertising for the company,. One of the most important things is that the chosen strategy is carried out and applied systematically.

Performance appraisal systems can be quite difficult to develop and implement, as a considerable number of factors must be carefully considered, such as what to measure, how to gather data in time, and how to report the collected information.

It is necessary to know that there is no definitely "correct" or "wrong" performance 
appraisal system that enables the improvement of the quality of services to the customers. Many different "researchers generally agree that the scale items are good predictors of overall service quality" (Brown et al, 1994) which is obvious from literature that incorporate theoretical discussions and applications of such instruments in a variety of industrial, commercial, and non-profit organizations.

Since 1985, the research of A. Parasuraman, Leonard Berry, and Valerie Zeithaml has produced a well-received measurement instrument for assessing service quality named simply SERVQUAL (Brown et al, 1994). It is based on the disconfirmation model widely adopted in the customer satisfaction literature and on the principle that the customer's assessment of service quality is paramount. Customer satisfaction is viewed in terms of the relationship between expectations and outcomes. The gap measures the difference between what customers expect by way of service quality "from a class of service providers (say, all opticians) and their evaluations of the performance of a particular service provider (say, a single Specsavers store). Service quality is presented as multidimensional construct." If the outcome matches the expectation, the customer's satisfaction is predicted. If the outcome exceeds the expectation, then the customer is likely to be delighted. If the expectation exceeds the outcome, the customer will be dissatisfied. This instrument measures 22 items of the customer's expectations and perceptions (Buttle, 1996.). The original design of the tool was later improved in several points through a series of subsequent works. Those identified five dimensions of a service: reliability, assurance, tangibles, empathy, and responsiveness. Each dimension includes four or five numbered items to measure them. The instrument is used twice in different forms, first to measure expectations and then to measure perceptions.

Literature is quite consistent in one point. It tells us that companies which develop customer satisfaction and service quality programs gain an important strategic competitive advantage. Since it has become ever more obvious that customer satisfaction influences the financial success, it will be necessary to introduce permanent market monitoring, in order to detect and understand, as much as possible, the facts that boost and influence customer satisfaction. The aim is to define the factor that attracts the 
customers in the first or in subsequent contacts, i.e. to define the reasons, which influence the customer satisfaction in the course of a long-standing co-operation.

Service quality is an comprehensive process. It opposes the tendency to focus just on the customer contact points. It directs attention to the interfaces between functional areas as the likeliest sources of service barriers and gaps. "Reliably delivering the service customer expects depends in part on how well various elements function together in a service system. These elements include people who perform the specific service in the service chain, the equipment that supports these performances and the physical environment in which the services are performed. Design flaws in any part of a service system can reduce quality. It is tempting to blame poor quality on the people delivering service but frequently the real culprit is poor service system design" (Berry et al, 1994).

That is why scholars and business executives have become increasingly interested in the concept of an organizational service orientation. Mounting evidence suggests that an organizational service orientation is a defining factor in the creation of superior customer value.

A company should listen to the customers and adjust to their needs. Business activities of companies should regularly undergo a circular process of planning and control. In this way, the company will be in a position to change a certain segment of business quickly, for the purpose of satisfying new requirements of customers as a prerequisite of retaining them. More customers are likely to leave a company because of poor service than because of product or pricing considerations. A true high-quality service distinguishes a company from the competition. 


\section{METHODOLOGY}

The usual approach to the measurement of service quality has been to use different gap models. Gaps are usually defined as the difference between the expected and experienced level of a service. One of the most widespread tools for measuring gaps and managing service quality is Servqual launched in 1985 by Parasuraman, Zeithaml and Berry. Although Servqual is one of the most common instruments for measuring service quality, many still contest some of its theoretical postulates (Buttle, 1996).

However, Servqual was not used in this paper, not because some of its theoretical postulates are disputable, but because it is based on measuring service quality at the point of contact between the customer and the company, i.e. it does not answer whether a company is organized around high-quality services.

Another way of determining the quality of service that will attract policyholders is certainly market research. At times it should also be an initial step in making further business decisions to achieve the best customer satisfaction possible. Regardless of numerous definitions, market research is best described by the statement that it is, in fact, listening to the consumers. Since a policyholder is a consumer (customer) of an insurance policy, all business activities of an insurance company must be oriented towards satisfying his needs. Nowadays, there are many divisions or guidelines for market research, be it the research of receivers of external/company services (external customers) or of receivers of internal services (internal customers, that is, employees).

Marketing managers are very familiar with conducting research the aim of which is to identify the needs of external customers. A similar approach may apply for identifying and understanding the needs of internal service customers. The management of internal service encounters requires "market" research in order to understand fully the needs of internal customers. Considering the volume of services produced and consumed by organizations internally, this issue of internal service consumption is of paramount importance. Such services as personnel, computing, and accounting, to name just a few, 
serve many different departments in most conventional organizational designs. In an effort to empower the personnel, companies have begun to challenge the old assumptions. One assumption is that these services must be provided internally, which requires the growth of the company in areas that are not of primary value to service quality.

It must be clear to the company that market research, regardless of the quality of questions and interviews with the customers or employees, cannot provide complete answers in respect to how to deal with a certain problem. Market research produces data that, provided that they are properly interpreted, should serve as the basis for managers who seek to find solutions to an existing problem.

The first objective of this paper was to understand the importance of service orientation and organizational development in that direction. My review mainly focuses on relevant literature that explores service quality and orientation and measures success of a company.

The available literature has shown that companies and researchers are aware of the importance of a company's service orientation for customer satisfaction and for the overall success of the company.

The second objective of this paper was to measure organizational service orientation of an insurance company in Croatia. To do that I had to find the instrument that would reliably measure the level of service orientation of the company from the employee's perspective. I believe that the research is best to start from the employees' viewpoint because they are also the internal customers of the company. They do know the company's internal strengths and weaknesses and can give a clearer and a more complete overall picture of the company's service orientation. Although the opinion of external customers is not less important, they have only a partial insight and therefore preference has been given to employees' viewpoint.

I believe that it is better to use a ready-made measuring instrument with proven measuring qualities (instrument reliability). The development of a new, specific instrument would prolong the research and would require time-consuming and extensive calibration of measuring characteristics. 
In 1998, Lytle and co-workers developed the SERV*OR instrument to measure organizational service orientation. Unlike most tools which measure the customer's perception, the SERV*OR is a managerial tool that can be used to measure employees' perception of service orientation existing within different work environments. It clearly specifies and measures key organizational practices, procedures, and routines indicative of an organizational service orientation. SERV ${ }^{*} \mathrm{OR}$ has proved the instrument of choice in specification and measurement of organizational service orientation for several reasons.

Although it has already been tested in various organizations, it has never been tried in an insurance company. However, strict methodology, multiple tests, and studies conducted across different industries (banking and home improvement retailing) corroborated that the instrument was sufficiently robust, enough reliable and psychometrically comprehensive to be applied in the assessment of organizational service orientation of an insurance company.

Lytle and co-workers tested the applicability of the tool in different socioeconomic environments, ranging from the US to a transitional Central European country.

With its help, one can clearly specify and measure key organizational practices, procedures and routines, which are indicative for service orientation of the company.

The simplicity of the tool allows utilization in various ways: from questions that are written in common language and easily understood by all employees - front-line workers, salespersons, managers, etc. - to examination of service practices and procedures by units and position within the unit.

Differing perceptions between units and positions can create a useful basis for exploring, understanding, changing, and improving service orientation within the company. To enhance service orientation might propel the company's position well ahead of the competitors. The results come in the form of the Lickert's scale of seven degrees. 
SERV*OR consists of 35 questions which serve to assess 10 dimensions of the most important practical features of an organization required to accomplish exceptional quality of service. The ten dimensions are (Lytle et al, 1998; Lynn et al, 2000):

1 Customer Treatment - employee's perception of the departments' or company's care for the customer. The level of care largely affects the quality of service. Organization's care directly affects the level of customer's satisfaction with the quality of service. Organizations that are invariably and completely focused on showing dedication to the customer are perceived as offering high-quality service, which is then rewarded by increased customer's satisfaction and loyalty and, in the long run, the organization's profit.

2 Employee Empowerment - employee's perception of the degree of the manager's confidence through entrusted authority, workload, duties, and responsibility. Managers may authorize employees to make decisions related to their everyday tasks. Equal distribution of rights, duties, and responsibilities encourages employees to make relevant decisions for the customer on the spot, that is, without postponing the delivery of a service until the clearance of the department head or management. Such delegation of authority helps an organization to meet more customers' requests, increase productivity, boost employee's motivation, and raise the quality of the service. As a consequence, the customer's perception of the service quality is favourable.

3 Service Technology - employee's perception of use of technology to accomplish exceptional performance. Technological superiority - when it does improve the service - provides a supreme value for the customer. Customer's expectations are often hard to fulfil even when aided by superior technology: personalization can be achieved through large and sophisticated databases, 24-hour access through free telephone service or web pages, and the service delivery must be quick. Superior technology is a basic requirement for a system providing high service quality, and 
the design and application of a technological system critically affects the success of a company.

4 Service Failure Prevention - employee's perception of the level of measures taken by an organization against errors in the delivery of services. It involves a design of a wholesome and smooth system based on the practice of proaction against error in service delivery. Such systems significantly affect the service quality.

5 Service Failure Recovery - employee's perception of the organization's strategic response to customers' complaints. Unless the organization manages to solve the customer's problem, it is liable to betray him twice: initially by committing an error and subsequently by failing to correct it. Research shows that companies, which have a planned and ready response to error in service delivery, are able to keep up to $95 \%$ of customer's who complained.

6 Service Standards Communication - employee's perception of the ability of an organization to make employees understand what are the expectations related to standards, work, and behaviour. Service quality is high in organizations that measure, control, and make known the standards of a high-quality service. All employees should be able to understand the standards and the basics of a service system for it to function effectively. Awareness of the standards raises the level of a service and reduces the risk of error.

7 Service Vision - keeping everyone informed about the idea of a good service. The sustained dissemination of a Service Vision among the employees stresses the importance of the service quality and of the customer's satisfaction for the organization's capital gain. Service Vision is disseminated by the department heads or the management to motivate the employees to reach a desired level of service. It clearly spotlights the aims and the crucial segments of a service, as well as their effect on the customer and his satisfaction.

8 Servant Leadership - the management gives example of proper service delivery. The examples are meant to motivate the employees to even greater commitment. 
Leadership is an integral part of management and is important for the organization's service orientation. Conscious or unconscious, managers' attitudes and behaviour at work have a direct and constant impact on the atmosphere in which a service is performed and on work results in a department and the entire organization. As long as the managers tend to be accommodating and to provide a role model rather than impose 'service policy', it is likely that the employees will follow their example in communication with the customer. Managers are those who set the standards by their behaviour and work. They actively participate in accommodating employee's needs according to accepted work standards. They inspire, motivate, and help their employees to accomplish outstanding levels of service.

9 Service Rewards - employee's perception of the organization's practice in rewarding service orientation. Most authors agree that an adequate system of rewards substantially affects the level of service and the customer's satisfaction.

10 Service Training - employee's perception of the organization's dedication to training in required services. Good training significantly affects the success of contacts with the customer. Leading service providers invest large amounts of money to raise the employee's communication skills above the usual smile and good manners, though these remain to be important. Successful organizations equally value training and technology investments. Moreover, technology is rather viewed as support to the employees, not their replacement. Service Training curricula produce better results in persons naturally inclined to providing services. This is why screening is the basis for successful service performance. 
In theory, each of the above dimensions has been categorized according to four general features associated with the quality of service (Lynn et al, 2000).

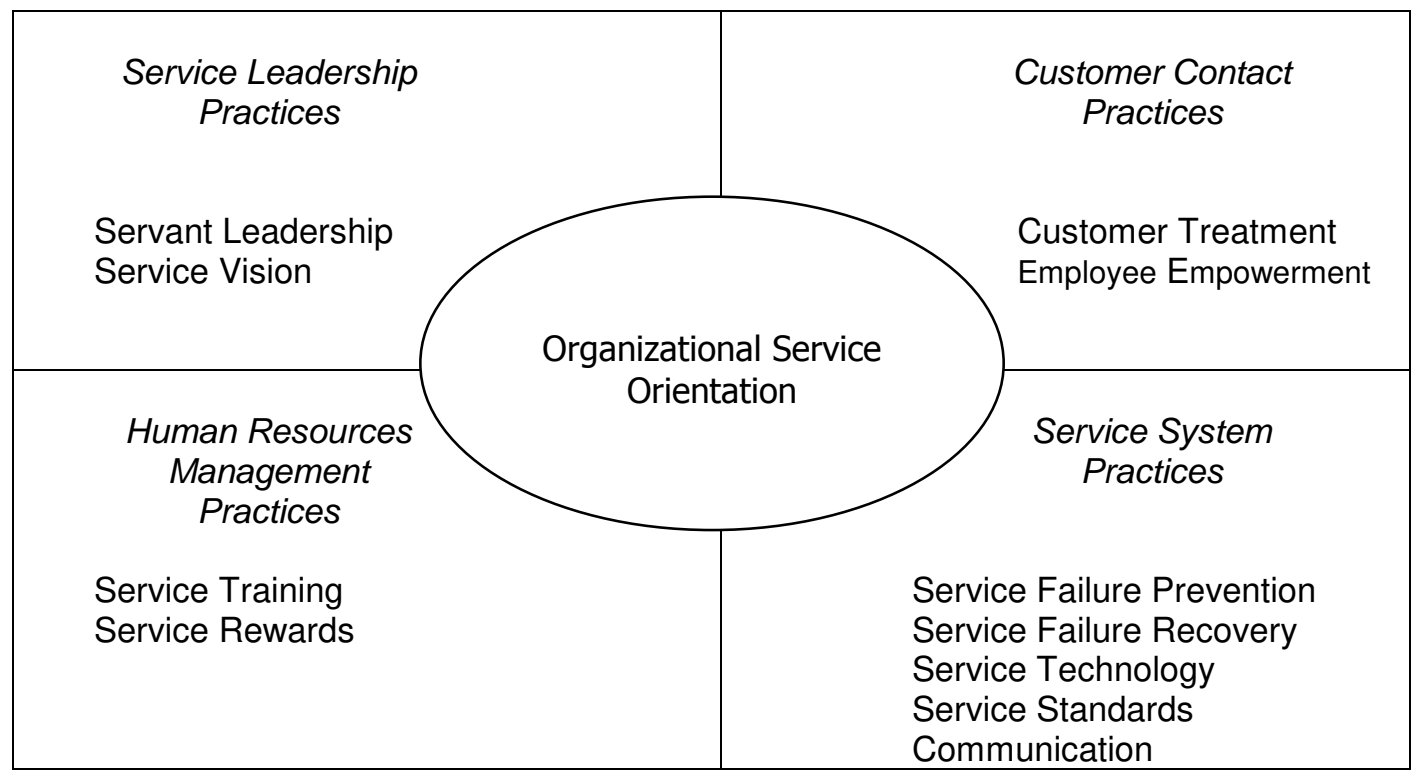

$\mathrm{SERV}^{*} \mathrm{OR}$ has been translated from English to Croatian and then to English. Misinterpretations due to language and cultural differences have been resolved through consultations with and between translators.

To verify whether differences in the perception of the Company as a service organization exist in relation to sex, department, hierarchy (combined with working experience), and regional office, which was the third objective of this study, additional questions were included in the original SERV*OR instrument. All subjects received invariable instructions how to fill in the questionnaire. The employees also received a cover letter by a member of the Board of directors in which he explained the purpose of the inquiry, asked the subjects to observe instructions, and stressed the anonymous nature of the questionnaire in hope of more sincere answers. The questionnaire included additional variables that were expected to significantly affect the results. The differences regarding those variables were analysed using descriptive and inferential statistics. 


\section{Respondents}

The inquiry included 102 respondents employed in an insurance company established as a daughter of an international finance concern in the Republic of Croatia since 1993. The questionnaire was distributed to all employees whether or not they came in contact with customers and regardless of the department in which they worked. Of 81 correctly filled-in questionnaires, 65 were answered by sales personnel and 16 by the personnel from backoffice departments. The inquiry included four regional offices throughout the country: Zagreb, Rijeka, Split, and Slavonski Brod that contributed with 30, 21, 21, and 9 correctly filled-in questionnaires, respectively. Forty-nine respondents were men and 32 women. Regarding hierarchy, 8 managers answered the questionnaire, 5 of whom worked in the sales department.

\section{Data collection}

To attain the first objective desk research was conducted between March and May 2000. Major articles and data were collected mainly from the Durham University Library via Internet. Other sources of data were the National and University Library in Zagreb and the Library of the Faculty of Economics in Zagreb.

To attain the second and the third objective, an internal market research with adjusted Serv ${ }^{*}$ Or questionnaire (see the Appendix) was conducted. The questionnaire was distributed to the employees simultaneously on all locations. The employees were earlier invited in a letter from a member of the Board of Directors to fill in the questionnaire and express their opinion about the functioning of the organization. They were assured that the questionnaire was anonymous and were asked to be sincere. The Board affirmed in the letter that it expected much from the questionnaire and that it highly regarded the opinion of the employees. 
The questionnaire was self administered by the employees/respondents under the guidance and monitoring of students of psychology who were given the consistent and strict instructions how to overview the completion of the questionnaire. All employees received the same questionnaire. They were seated in such fashion as to prevent one influencing the other's responses. The time for completion of the questionnaire was not limited. Before the start, the respondents were instructed how to fill in the questionnaire. Once again, they were invited to answer it sincerely and without restraint.

The completion time ranged between 15 and 30 minutes. All questionnaires were collected, coded, and sent to the Company's headquarters for further processing in the database.

The questionnaire was coded and the respondents were grouped by sex, department, hierarchy, and regional office. Of 102 distributed questionnaires, 81 were filled in correctly (79\%). The response from the regional offices and departments was $100 \%$. The collection of questionnaires and the database input were completed in June 2000. 


\section{RESULTS}

The purpose of this study was to:

1. Understand the importance of service orientation

The data were collected from all respondents-employees of the Company and the arithmetic mean and standard deviations were calculated for each of the ten SERV*OR dimensions (Table 1).

SERV ${ }^{*} \mathrm{OR}$ measurements of the service orientation of an insurance companies have not been recorded earlier neither in developed nor in transitional countries.

To get an idea of the service orientation of the Company, however, I had to compare my results with a SERV*OR profile of another service provider. It seemed the most appropriate to compare them with the profiles of two Slovenian banks, one in private and the other in government's hands (Lynn et al, 2000) because of common features such as financial activities and close geographic and economic relations (Table 22 and Figure 22).

The authors of SERV ${ }^{*} \mathrm{OR}$, who studied the two Slovenian banks, established a correlation between business results and the results of SERV*OR. Namely, the private bank showed better SERV*OR results, which pointed to better service orientation, and in fact made better business results than the government-controlled bank.

Lynn and co-workers found that the private bank ranked seven of ten dimensions of the organizational service orientation significantly higher than the government-controlled bank. The comparison between their results and ours show that the Company stands between the two banks. Service Failure Recovery, Service Leadership, Service Rewards, and Service Training ratings are closer to the private bank, whereas Customer Treatment, Employee Empowerment, Service technology, Service Standards Communication, and Service Vision ratings are closer to those of the government-controlled bank. The 
comparison suggests that the service orientation of the Company is altogether closer to the government-controlled bank.

The government-controlled bank achieved inferior business results, which was associated with weaker service orientation with respect to the private bank. It is likely that an increase in the ratings of the $S E R V^{*} O R$ dimensions - this refers to all ratings except Customer Treatment (above 5) which are now below the neutral and below the ratings of the private bank - could reflect in better business results of Company.

2. Measure organizational service orientation (from the employees' perspective) of an insurance company in Croatia

Lickert's scale (Figure 1) shows the company's profile, which facilitated the analysis of the employees' perception of the organizational service orientation with respect to the ten dimensions. As low values represent complete lack of service orientation and high values its full implementation, the profile of the Company generally concentrates around the neutral value. Except perhaps for Customer Treatment, none of the ten dimensions stands out. The results of our inquiry show that all employees gave the highest mean grade to their attitude toward the customer (mean $=5.23$ ). The employees associate this substantial accomplishment in contacts with customers with their personal skills and adaptability. Quite expectedly (Bitner et al, 1994), studies show that employees are reluctant to associate the customer's dissatisfaction with their own shortcomings, attitudes, or behaviour.

The finding suggests that none of the dimensions of service orientation has developed in either direction, that is, the employees do not decide whether the Company had a strong or a weak service orientation. The conspicuity of the Customer Treatment dimension reveals the employee's opinion that their effort and commitment is the only outstanding dimension of the organizational service orientation. Further analysis shows that the subjects' evaluation of the following dimensions slightly exceeds the neutral: Service Vision, Service Training, Service Failure Prevention, Servant Leadership, and Service Failure Recovery.

The results suggest that the employees believe that in these dimensions the Company 
accomplished a certain level of service orientation that may result in favourable perception of the company by the customer.

Service Technology, Service Rewards, Service standard communication, and Employee Empowerment were rated below the neutral value. The subjects believe that the company should strive to develop these dimensions to improve its service orientation. Employee Empowerment received the lowest total rate (3.43), which suggests that the employees would welcome more responsibilities, authority, and duties to meet the customer's requirements more efficiently.

3. Verify whether the respondents differed in the perception of the Company as a service organization with respect to sex, department, hierarchy, and regional office

Further, I analysed the differences between managers and the rest of the employees in the perception of the service orientation of the Company. Table 2 and Figure 2 show that the two groups differ most in the perception of Service Standards Communication, Service Training, and Service Failure Recovery at a statistically significant level. The results show that, as a rule, managers perceive the Company less service-oriented than do the rest of the employees. One could seek an explanation in the fact that managers have a detailed and broader insight in everyday business problems. Managers believe that most dimensions require stronger commitment to improve the company's service orientation. Nearly all employees agree that the attitude toward the customer is above the neutral, yet the attitude cannot compensate for shortfalls in other dimensions.

Then I analysed differences between the sexes. Table 3 and Figure 3 show that women and men differed, though not significantly, in the perception of the company's service orientation. Women tended to rate the ten dimensions lower than men and the difference was significant in the dimension of Service Training.

As often pointed out, the Company is divided in the Sales department and the back-office 
departments. The first sells insurance and the second provide support to customers and/or the sales department. This is why I analysed the differences in the perception of the company's service orientation between the sales and the back-office employees. The comparison shows that their perception significantly differs in nearly all of the ten dimensions. Table 4 and Figure 4 show that the Sales department has the most favourable perception of the Company. It perceives the Company as more serviceoriented in six out of the ten dimensions; the employees have the opportunity for training, the system of rewards is well-developed, managers are perceived as service-oriented and confident of the employees, as they give the employees the authority to make decisions, which in turn speeds up and improves service delivery.

Back-office departments rated Service Technology significantly higher, because information technology fulfilled their needs far better than those of the sales department.

The Sales department rated the Service Failure Recovery significantly higher than did the back-office departments. The reason may lie in the fact that internal services receive far more complaints in writing or by phone and that the lack of internal standards and communication results in unfavourable perception of the failure recovery system by the back-office services.

The results of other departments indicate that their employees perceive the Company's service orientation as below the neutral. Beside Customer Treatment, Service Technology is the only dimension, which received a grade close to five, whereas other dimensions received neutral or lower rating.

Back-office departments rate Service Standards Communication significantly lower than the Sales department; in fact this dimension received the lowest average rating. In other words, back-office departments are the most affected by the lack of internal standards and procedures, as it discourages better service performance. The lack of internal standards and procedures may lead to inadequate, late, and often diverse response to the customer's requirements. This puts the employees who contact customers (internal or external) in an awkward position, as they do not know how to respond. By contrast, the Sales department pays much more attention to standards and their internal dissemination. 
This is why their rating of the dimension is significantly higher.

Back-office departments are significantly less aware of the Service Vision than their Sales colleagues, most probably due to a lack of internal communication. The same may be the reason for the significantly lower rating of Servant Leadership of internal service managers than of the Sales managers by the respective personnel.

Service Rewards was also rated significantly lower by the back-office departments than by the Sales department who ranked neutral the system of rewards. In other words, backoffice departments complain of inadequate stimulation and lack of motivation for quality service.

The back-office departments gave Service Training the lowest average rating. By contrast, the rating by the Sales department was the highest and the difference between the two was significant. Back-office departments believe that the level of training does not meet the service requirements and that the awareness of these requirements is also lacking, as can be inferred from the rating of Customer Treatment. The latter dimension received equal rating by both groups.

Though not significantly, the perception of Employee Empowerment is also better in the Sales department. This finding suggests that back-office departments would appreciate more authority without shirking from responsibility, as it would improve the service quality and satisfaction with one's work.

The significant differences between the Sales department and back-office departments called for a more elaborate analysis of differences between single departments. To be able to understand what follows the reader should understand the distribution of tasks and authorities among departments. The Insurance Policy Processing deals with requests for life or property insurance. The Claims process requests for compensation of damage. The Finances take care of the company's financial business. The Common Services include the secretaries of the office, legal office, and the office for personnel training. The Sales sell the insurance policies. 
The comparison between the Sales department and Insurance policy processing (see Table 5 and Figure 5) point to a significantly different perception of Service Technology which is rated much higher by the Processing than by the Sales (as I already pointed in the analysis of sales and back-office departments, information technology fulfilled the needs of back-office departments far better than those of the sales department). The difference was also significant in the dimension of Service Leadership, as it received significantly better rating of service orientation in the Sales than in the Processing. The third difference was observed in the dimension of Service Training. The perception of the possibility to improve the approach to the customer through training is significantly better in the Sales than in the Processing.

Table 6 and Figure 6 show the differences between the Sales and Finances. The Finances rated Employment Empowerment significantly lower than did the Sales. The same is true for Service Standards Communications, which in turn points to the lack of internal standards and communication. The rating of Servant Leadership, Service Training, and Service Rewards was also significantly lower by the Finances.

The comparison of results between the Sales and Claims (Table 7 and Figure 7) reveals equal perception of Service Technology. In other words, the Claims find the information technology for processing claims below operational standards that would enhance service orientation to the customer. The Claims' perception of Service Failure Recovery, Service Standard Communications, Service Vision, Service Leadership, Service Rewards, and Service Training is also significantly more unfavourable than that of the Sales.

By contrast, the Sales and Common Services significantly differ only in Service Training (Table 8 and Figure 8). 
To sum up, the comparison between the Sales department and back-office departments collectively did not significantly differ from the comparison between the Sales and individual services. Yet, I decided to look into differences between back-office departments to get a better insight in these relations and perhaps find a way to improve them.

Table 9 and Figure 9 show the results of comparison between the Finances and Policy Processing. The two differ in the perception of Employees Empowerment, which received significantly lower rating by the Finances. This was also true for Service Technology. The two offices equally rated Service Vision; the average mark of this dimension was somewhat below the average mark of the entire company. There were no statistically significant differences between the two offices with respect to other dimensions. In substance, the Finances perceive the company less service-oriented than does the Processing.

The Processing rates higher the company's service orientation than the Claims in all dimensions, but the difference is statistically significant for Service Failure Recovery, Service Standards Communication, and Service Vision (Table 10 and Figure 10).

The comparison between the Processing and Common Services (Table 11 and Figure 11) shows that the two significantly differ in the rating of Employee Empowerment.

Consistently, Claims have a less favourable perception of the overall service orientation than do the Finances (Table 12 and Figure 12). The biggest difference between the two perceptions concerns Service Vision at the level of statistical significance. The two also significantly differ in the rating of Service Failure Recovery and Service Standards Communications.

The Finances' perception of all dimensions is less favourable than that of Common Services (Table 13 and Figure 13). Statistically significant differences were found for Service Standards Communications, Service Rewards, and Service Training. 
Similarly, the Claims rated all dimensions lower than did the Common Services (Table 14 and Figure 14) and the difference was significant for Service Failure Recovery, Service Standards Communication, and Service Vision.

Further analysis focused on possible differences in the perception of service orientation of the Company between regional offices and the headquarters in Zagreb, as these differ in the scope of services. Table 15 and Figure 15 show that the headquarters employees have a more favourable perception of Service Technology and Service Failure Prevention than do the regional offices. Though not significant, the difference is grounded in the fact that the headquarters are the major user of information technology.

By contrast, the headquarters rated significantly lower Service Standards Communications, Servant Leadership, Service Rewards, and Service Training than did the regional offices. One may seek an explanation in the fact that regional offices mainly consist of sales personnel, which, according to our results for the entire company, tends to favour the three dimensions. The results also indicate that distances do not affect good communication between the sales offices.

The finding of many statistically significant differences prompted an analysis between individual offices and headquarters. The purpose was to see whether our interpretations of differences were correct.

The comparison between offices in Zagreb (headquarters) and Rijeka (Table 16 and Figure 16) confirms the difference in the perception of Service Technology. Rijeka rated it significantly lower than Zagreb because the technology is objectively less developed in Rijeka than in the headquarters. By contrast, Rijeka employees have a significantly better perception of Servant Leadership than Zagreb, perhaps due to reasons described above. 
The comparison between Zagreb and Split (Table 17 and Figure 17) confirmed the significant difference in the perception of Service Technology, which is favoured by the headquarters. Split, in turn, favours several dimensions, but the differences were significant for Service Standards Communications, Servant Leadership, and Service Training.

The comparison between the office in Slavonski Brod and other offices (Tables 18-20 and Figures 18-20) revealed a curious tendency of the Slavonski Brod employees to rate all dimensions of the company's service orientation far more favourably. The only dimension in which the offices did not differ significantly was Service Failure Prevention. Altogether, The Slavonski Brod office showed the highest level of satisfaction with work in Company.

The comparison between Rijeka and Split did not reveal significant differences (Table 21 and Figure 21). 


\section{DISCUSSION}

Many managers in practice and many authors in their studies established an obvious relationship between the quality of service and costs, profitability, customer's satisfaction and loyalty, and recommendations by word of mouth (Lynn et al, 2000).

Insurance companies are a classical example of service companies. For centuries they have been delivering to their customers nothing else but service alone. Furthermore, in many cases, the service is never actually delivered at all. The fact that service providers such as insurance companies deliver nothing but services for money makes the customer's loyalty completely dependent on the service quality or its improvement. At the same time, the customer is reluctant to pay more, as he feels that he has already paid for the top service (Zeithaml et al, 1996). What is it that insurance companies have to do to attract and retain their customers?

The relationship with their potential and existing customers has to be first class. This means that if claims are to be processed fast and impeccably. Moreover, if a customer has additional requests or questions, the company has to answer them in a way that will increase his trust in the company. Insurance companies have dozens or even hundreds of thousands customers and numerous modifications from standard products that practically enable each customer to get products adjusted to his or her needs. To ensure fast, reliable, and correct treatment of so many requests and questions, insurance companies have to choose and empower their employees with great care. Employees have to be competent and qualified to make correct decisions in their everyday tasks. The process has to allow for decision making on the spot because any bureaucratic delay may dissatisfy the customer. 
Insurance companies have to grow in size and markets to maintain broad customer basis, to be able to meet their requests and assume the risk.. This is the prerequisite for the delivery of a high-quality service. It is even more important that the management of the company has a clear vision of the company's development and of the real measure of high-quality service. The management has to share this vision with other employees by setting an example. This is the most appropriate and effective way to communicate the company's service standards to all employees.

Service standards and state-of-the-art technology devised to track diverse long-term contracts which are subject to modifications and which are customary for the insurance services serve well in preventing as well as remedying errors. Insurance companies pay attention to the training of employees because the sale primarily involves face-to-face contact, especially in life insurance which requires higher skills and knowledge. Proper remuneration in insurance industry is mostly based on the commission principle.

This study is a contribution to the efforts to see to what extent service orientation affects financial and market results of an insurance company.

The findings of this study will help to see the shortcomings of the Company in service orientation and to identify organizational factors that hinder even better results. They can be used to improve the quality of the external customer's experience in communication with an insurance company. The company should encourage positive attitude toward the customer to reach an objectively high level of service quality and have employees satisfied with their work. Several studies of satisfaction with service suggest that communication between the customer and the vendor best defines the customer's satisfaction. A study of relationship marketing in the life insurance industry (Crosby and Stephens 1987) showed that the contact with personnel significantly defined the overall customer's satisfaction with the service (Bitner et al, 1990). 
As I mentioned earlier, the Company is a daughter of a 170-year-old insurance company. It was founded in 1993 and the main part of its turnover comes from life insurance. The recession (unemployment, internal and external debt) in the country forced some customers to terminate the existing contracts or to decrease the risk-coverage. Bankruptcies of other finance institutions (banks, savings-banks, or insurance companies) have led to great scepticism about the finance industry. At the same time general population has little knowledge about the nature and mechanisms of insurance, yet people will sooner refuse to buy a policy than admit that they do not understand the issue.

The Company has the greatest share in life insurance on the Croatian market and it has achieved that in 5 years of work. It has developed a powerful sales force combined of employees, freelancers, and agencies. It is perceived as the first international insurance company in the country with the background that guarantees safety of investment. Due to orientation toward life insurance, the Company did not pay much attention to other service products (car insurance, property insurance) and accompanying services (claim experts i.e.) With the right strategy, however, those weaknesses become advantages; the Company has still in stock new products to offer and new towns and places to cover, which may significantly boost the Company's development in the long run.

Due to a strong initial growth the Company did not pay attention to internal development and organization. The number of employees has grown rapidly, but the structure has hardly changed from the period when only a few persons worked there. Technical and organizational solutions of the mother-company are sometimes inappropriate and may cause delays and errors in everyday tasks. This is especially visible in service failure prevention and recovery, because different market approaches are covered with same information technology. 
The findings suggest that the Company is sales-oriented insofar as it favours the development of certain dimensions over others in providing service to the customer. The analysis reveals that the focus is on those employees who come in contact with the customer. Less attention is given to the fact that a service-oriented company should start with the attitude and communication within the company. The improvement of internal service quality is crucial for the survival of a service provider. Service quality is one the important functions of the service system. Focusing on good manners may get the company going for a moment, but in the long run, only changes in the organization may bring sustained improvement. Failure doubles the cost of the service because it has to be redelivered or a damage compensated; it also leads to the loss of customer and of reputation by word of mouth, and finally to a fall in the employee's morale (Bitner et al, 1994). In other words, the internal structure of the organization should become more service-oriented and this attitude will necessarily reflect in the improvement of the quality of service to the customer.

The findings of our study give basic directions toward the changes. I will analyse them by individual dimensions:

1 Customer Treatment - This dimension of service orientation received the highest rating from the employees of the Company and was the only to exceed the neutral value $($ mean $=5.23)$. Invariably all departments share the opinion that their people give their best to satisfy the customer. This means that the employees are intrinsically motivated and highly committed to their work. The employees often seek to compensate for the system's shortcomings with additional personal engagement. Such commitment is the best possible foundation on which to develop a systematic service structure of the organization that would aid the employees to serve better the customer and show its full creative potential. The company is strongly advised to recognize this commitment, to acknowledge it, encourage it, and highlight it. The company is also advised to pay attention to what the employees have to say about problems standing in the way of better service, and to act accordingly. Should the company continue to disregard the potentials of its 
workforce and the need for structural changes, the number of the dissatisfied and motiveless will increase. The consequent fluctuation of the best workers will only increase the existing difficulties and costs.

2 Employee Empowerment - This dimension related to the perception of delegation of authority and responsibilities received an average mark of 3.43 , which in effect means that the employees do not think they have the autonomy to make decisions that would improve service performance. This dimension received similar rating by the Slovenian government-controlled bank (mean $=3.28$ ) and significantly higher rating by the private bank (mean $=4.16$ ). Autonomy to decide helps to develop a sense of responsibility and increases motivation in personnel. The familiarity with the concept of service, its performance, and internal standards empowers the employees to give information to the customer, review the possibilities, propose a solution, and explain why something cannot be done or a requirement met. Employees are aware that they are responsible for the service quality and give their best to accomplish a task. Research shows that the employee's ability to meet the customer's requirement corresponds to their knowledge and assigned authority (Bitner et al, 1990). Failure to delegate authority is interpreted as a lack of confidence, which in turn undermines personal commitment. Inability to make decisions collides with the intrinsic disposition to satisfy the customer, and this in turn leads to frustration. Having in mind that the Company's departments significantly differ in the rating of the entrusted authority, it is necessary to further investigate the reasons for the difference, analyse the everyday tasks of the employees, and find a way to give them autonomy, especially in those decisions which concern direct response to the customer's needs. It is necessary to encourage the employee's initiative, not to quench it.

3 Service Technology - The altogether rating of the application of high technology to satisfy the customer was below the neutral (mean $=3.88$ ). This result corresponds to the rating of the government-controlled bank (mean $=3.46$ ), whereas the Slovenian private bank stands out significantly (mean $=5.19$ ). To run successful business without high technology has become unthinkable. In the world of swift 
changes information is money. Those who have information are able to make competent decisions and sustain the competitive advantage. Departments differ in information requirements. Those that process information have different demands from those that do not. Namely, case files or bookkeeping entries are reasonably retrievable, whereas the sales data with daily, weekly, or monthly updates are not, which puts decision makers in an awkward position, as they rely on unreliable data. Yet, the dynamics of the Sales department requires quick decisions and these should rely on precise knowledge of the market situation at any moment. Unless the company's action is founded on actual market situation - which is not the case, according to the perception of the Sales employees - it falls short of desired results. Some departments are fully satisfied with the technology and some not even slightly. These results show that the company lacks a single organizational strategy that would make all departments aware of each other's role. Fulfilling only immediate tasks is the ultimate care of each employee. The incomplete picture renders flawed satisfaction with work, as one is not aware whether or not those tasks make sense for other departments or the Company as a whole. Another issue is that the Company should establish what information is required by which department in order to serve well the customer. The two issues should be solved together.

4 Service Failure Prevention - The rating of this dimension (mean $=4.66$ ) is below the rating of either government-controlled (mean $=5.69$ ) or the private bank (mean $=5.72$ ) and suggests that the company's prevention system is ill-designed. As a stitch in time saves nine, it is necessary to analyse the history of the system failures, see if there is a pattern, and make an elaborate prevention strategy that would clearly define the role of each department. Employees who contact customers are not always to blame for a bad service. The error may be due to inadequacies in means of work, organization, internal communication, instructions, equipment, or procedures. It is also necessary to follow up the customers' satisfaction with the service, define potential difficulties and expectations, and revise the strategy accordingly. 
5 Service Failure Recovery - The average mark for this dimension of the Company is 4.09 , and exceeds the corresponding ratings of the Slovenian banks (government-controlled 3.39 and the private 4.06). It seems that the Company gives greater priority to the development of the failure recovery system than to prevention. However, this dimension also received neutral judgment and needs structural improvement. It is easy to determine the cost of each error in the system by calculating the recovery costs or the costs of the loss of a customer. As with the previous dimension, it is necessary to analyse the present recovery procedure and determine its shortfalls and advantages. The increased efficiency of the revised recovery system should render the entire service system more secure for the customer.

6 Service Standards Communication - This dimension received the average mark of 3.67. The rating is closer to the Slovenian government-controlled bank (mean = 3.32) than to the private bank (mean $=4.20$ ). This dimension reveals the internal organization and communication. It answers whether the employees are fully aware of all service standards in all departments, whether there is a unifying set of goals for all departments and offices, whether there are internal standards to warn about an error before the customer complains, and whether the results of the service and customer follow-up are made known to all employees, regardless of their position. The Company as a whole ranks below the neutral with that respect. The results point to a lack of internal standards that would facilitate operation and finding solutions to everyday situations not involving the managerial authority. The managerial position entails better insight in the company's structure and its shortcomings are directly felt. The lack of internal standards and consequent misunderstandings are perceived as a burden to business. Employees focused on more concrete tasks share that perception to a lesser degree. It is obvious, however, that the lack of internal standards and communication reflect the failure of the Company to produce such back-office structures that would ensure better service orientation. Instead, it encumbers business management. The perception also significantly varies from department to department. The company should 
immediately review the existing standards and goals in order to establish whether there are any, to what extent the employees are aware of them, and whether they serve the company's purpose. It is also a priority to investigate how familiar are the employees with the procedures in other departments and what is their perception of their department's contribution to the company. Further review should reveal what are the everyday problems in communication between departments, is information relevant for decision making instantly available, is missing information (re) traceable, is the available information satisfying qualitatively and quantitatively, is the company's strategy clear, and so on. The answers should help to design the missing internal procedures necessary for providing adequate service to the customer, cancel obsolete procedures, and design a system of internal communication that will be able to communicate the company's vision, strategy, and goals, and to meet information requirements of each and every department.

7 Service Vision - The average mark for this dimension is 4.69 and is closer to that of the government-controlled bank (mean $=4.66)$ than to the private bank (mean = 4.75). The differences, however, are not statistically significant. In effect, the employees of the Company neither agree nor disagree with the statement that the organization is sincerely committed to delivering the service, that the customer is viewed as an opportunity to deliver a service, and that the company, in fact, exists to satisfy the customer. Having in mind the sales orientation of the company, this attitude is understandable. There are too many organizational failures that blur the perception of the Company as truly service-oriented. Without knowing every single detail about what one is committed to deliver, it is impossible to know how to deliver it and whether it has been delivered it after all! The Company should organize itself around the customer's goals and not the company's goals, because only by reaching the customer's goals shall the company be able to win them or keep them. At the same time, it will accomplish the company's goals far better than if it limits itself to its narrow interests. The advice is that the Company should strive to improve service orientation in all external and internal features of the Company, as well as the sustained dissemination of awareness of these features. 
8 Servant Leadership - The rating of this dimension of the Company (4.56) was closer to the Slovenian private bank (mean $=4.66$ ) than to the government-held bank (mean $=3.26$ ). This result would have been promising and the company could have continued to develop an image of management as service-oriented, had not the departments differed so significantly. Namely, some departments were utterly displeased with the managerial example. To change it, the company should make a uniform strategy for service-oriented management. Managers should be aware of the importance of this concept, of its implications, and ways to make it work. Service-oriented managers are there to serve the workforce, to inspire it, and facilitate its performance. They should perceive their position as steering and standard-setting. They should be confident of their employees and give it them the opportunity and freedom to complete their tasks. An organization cannot demand proper behaviour toward the customer from its employees, unless it sets an example by its behaviour toward the employees. Furthermore, the employees should learn what to expect from a service-oriented management.

9 Service Rewards - The Company rated this dimension more favourably than the government-held or the private bank (3.80 v. 2.84 and 3.70 , respectively). The comparison suggests that the system of rewards is designed better in the Company than in the Slovenian banks, yet it is still below the neutral. The comparison between departments shows that only the Sales expressed its satisfaction with the system of rewards, whereas other departments were considerably displeased with it. This is yet another confirmation of the sales orientation of the company. Highquality service should be rewarded irrespective of the department, because they equally share the merits. At the same time, lame results in a single department will affect the whole company. This is why the Company needs to conduct an audit of each department, devise a reliable tool to measure individual contribution to highquality service, and develop a concise and clear system of rewards. A follow-up and reward system will be able to show the weak points of performance. Once these are improved, the whole system will be upgraded. 
10 Service Training - The average mark for this dimension was 4.69 , that is, in between the two Slovenian banks, yet closer to the private bank (mean $=5.19$ ) than to the government-held bank (mean $=3.46$ ). Again, these dimensions should be viewed through significant differences between the departments. Quite expectedly, the most favourable perception of training was that of the Sales department (sales orientation), whereas other departments rated it significantly lower. The fact that the back-office departments play a crucial role in customer care and post-sales marketing suggests that the low rating of Service Training dimension calls for serious and immediate changes, as it may adversely affect the entire company. Back-office departments seem to believe that their role is underrated. As, in a way, SERV*OR measures the employee's satisfaction with its organization, these results suggest that the back-office departments are significantly less satisfied with their status than the Sales department. As with the previous dimension, the company should audit each department, see what segments can be improved, and secure proper training of the employees. However high the costs are, the training will improve the service quality and increase the customer loyalty rate. Training requirements should be determined by internal standards and the ability of the employees to meet them, not by hasty decisions. Failure to meet a standard should be the basis for deciding about the type and the level of training. 


\section{CONCLUSIONS}

1. This paper has corroborated the association between service orientation and successful achievement of business objectives and has stressed the importance of development of the insurance company in that direction.

2. The results of the measurement of service orientation of the Company from the employees' viewpoint using the SERV*OR instrument are around neutral, which means that the employees see their company as neither service oriented nor nonservice oriented.

3. The results also show that the perception of respondents varies according to hierarchy, regional office, and department in particular.

4. The results of the primary and secondary research give clear directions as to the further steps of the Company to achieve a higher level of service orientation and better business results.

\section{Managerial implications of the findings}

The below suggestions for managers rely on the study results, my experience, and data from the reviewed literature. The intention is to help managers to develop service orientation in their insurance company.

Changes on the market are swift. The only chance to remain competitive is to recognize and meet the changing requirements of the customer. It may have sufficed earlier to have competitive prices and technology, but the pressure of fierce competition has now grown sky-high. Customers no longer tolerate fuzzy service because they have a choice! 
As an insurance company, the Company can only offer services to the market. One would therefore expect that SERV*OR results of such company concentrate around higher values. Our findings show that its employees do not perceive those services as different, or following different market principles from any other 'material good or object'. Having in mind that the Company is leads in a specific type of insurance on the Croatian market, one realizes that its achievements do not reflect the internal structure of the company, but rely on the sales and may well crumble, unless supported by solid foundations.

The results show that the sales personnel has a much better opinion of the Company than the back-office departments. The fact reveals the company's strategic orientation toward sales, which includes training of the sales personnel and the development of the system of rewards to achieve better results. Developed countries tend to abandon such orientation, as it eventually exhausts the market instead of expanding it through new goods and/or services or new customers. What affected such change in orientation of successful companies was the discrepancy between supply and demand. In other words, the substantial increase in supply was not followed by a corresponding increase in demand. The situation prompted companies to focus on keeping customers and on increasing the awareness of needs, which in turn would increase the demand. To achieve the two goals, companies had to restructure substantially and become able to follow swift changes on the market.

The strategy of the Company is short-term and sales-oriented, as it gives priority to selling as many policies as possible over the customer's satisfaction. Modern successful companies, regardless of what they produce or sell, found their business on the customer's requirements and ways to meet them. The internal structure of such companies is completely in function of that goal. Many studies have shown that customers value companies by their effort to devise a complete solution for their needs (information services, after sales marketing, maintenance, and so on). 
This is even more true for insurance companies, as they sell services. The results of this study suggest that generally neutral or low rating of the service orientation of the Company and the present business strategy may soon lead to the loss of the market position to an insurance company with better attitude toward the customer's needs or more service-oriented internal structure.

The sales orientation of the Company and its efforts to train salespersons that can solve problems for the customers give a false idea of the company's service orientation. One soon discovers that all departments do not equally share the quality of service and approach to the customer and that the internal communication needs improvement. It is only logical for the customer to ask how can such company help him if it can not help itself, how can it promise a total service if it fails to see its limits. A customer evaluates all parts of a service before she or he decides that a company is service-oriented and worth the while. This is why a company should shift the focus from external appearance to deep structural changes as a prerequisite for developing into a service-oriented company.

Unless the employees are aware of the company's ideas and vision, of what it can offer to the customer, of what that offer consists, and what is the role of each and every employee in the company, they will not be able to do their job, that is, to satisfy the customer. Even partial ignorance of the company's plans and activities may eventually alienate the employees from work. When assuming office or position, an employee believes to know her or his role and is motivated to give her/his best. The daily routine, however, might soon disillusion, confuse, and frustrate the employee. She or he may be denied access to crucial data, not receive support by colleagues from other departments, lose the superior's confidence, have restricted authority, and be unable to make decisions. No one may lend an ear to her or his ideas and proposals. The frustrations do not go unnoticed by the customer, as they are printed on the employee's face, attitude, and performance. A spark of the customer's mistrust may easily turn into a resolution to find a better company. As the cost of attracting a new customer is much higher than the cost of retaining one, it is obvious that each loss does enormous damage to the company. 
Our analysis shows that the Company lacks uniform business strategy. Differences start from the top with each manager having her or his own idea of how to run the department. Unequal is the approach to the needs of the employees in order to achieve better business results. The same goes for the level of access to information and the dimension of Servant Leadership, that is, the perception of how successfully managers set an example.

Employees in constant contact with customers, unless they are aware of the company's structure and limits, are unable to explain to the customer why there is so much red tape or why they are not allowed do something. Our results concerning Service failure recovery and Employee empowerment corroborate this observation.

One source of problems with services, especially in service providing companies, is a different approach to rewarding the work between departments (sales, finances, and so on), which in turn determines the approach to the customer. Disagreements may stem from differences in skill, possibilities, and short-term goals. Such system brings confusion among the employees and frustration to the customer. A company must appear as a unity, and as such it requires internal coordination and focus on the customer, regardless of the department. Anything else would produce discontent, a drop in motivation, greater fluctuation of good workers, and eventually caving in of the company.

In the face of the marketing theory and practical findings, the Company has not yet taken steps to shift the focus toward service or marketing orientation as a single, long-term approach toward successful business. This is what makes it vulnerable and likely to fail before the competition. 


\section{Recommendations}

The Company should urgently design a system that will be able to produce higher rating of all dimensions of the SERV*OR measurement. The first task is to make a detailed assessment of the present situation, determine the company's strengths, weaknesses, opportunities, and threats (SWOT), and restructure it into a company with a single vision, unified service-oriented management and departments, and seamless cooperation between them.

The Company is the leading life insurance company on the Croatian market. Its development strategy is to take a greater share in other insurance services as well. Unless the company restructures to improve service orientation, it will lose the competitive edge to a more service-oriented company as soon as it shows up on the market. The example of the two Slovenian banks is clear; the company with the better rating of service orientation accomplished better business results. The same will prove true for insurance companies differing in the SERV*OR measurements. The Company should act today to be able to confront the risks of tomorrow. The change will not be univocal and visible shortly, as it requires time, a change in behaviour, management support, removal of all who oppose the changes, highly developed cooperation, and reliable assessment of individual contribution. It is crucial that the company's service goals embrace individual goals of each and every employee. It is not easy to implement these ideas, yet unless the changes are completed the employees who put much effort and hope in those changes will start to feel let down by the company. The rewards for changes brought to completion are the increased service quality, greater customer's satisfaction, and the consequent increase in the market share and profits as the key stimulator for the company to start implementing the changes. 


\section{Further investigation and activities}

This study was the first to measure service orientation of an insurance company using the $\mathrm{SERV}^{\star} \mathrm{OR}$ method. There are many relevant issues that call for analysis. Many studies of service industries have paid more attention to the opinion of the outside people about the service orientation of a company. Instead, our study showed that internal perception is equally important for the success of a company. Measurement of the internal quality of service is crucial as it directly and significantly affects the level of service to the customer.

This study has shown that the internal structure of the Company is underdeveloped or misdirected with respect to certain dimensions of service orientation. The employees are in a position to have a better view of the external and internal delivery of services than the customer. This is why the company should investigate how the system and its parts operate in order to provide services that are perceived as crucial by the customer.

All too often the blame for a bad service falls on people who deliver it, rather than on an illdesigned system (Berry et al, 1994).

Inquiries with the employees can reveal the sources of problems and suggest solution. Everyday involvement and experience prompt an employee to react and solve a problem before it affects the customer. Further investigation of problems encountered in back office departments should help the company to improve the structure and cooperation between the management and the employees. 
The use of the Critical Incidents technique offers that possibility. As one department often receives services from the other, or even from within the department, this technique may help to determine information relevant to the employees and their work. It is important to stress that education about the customer's requirements should not limit itself to lectures and instructions, but it should include workshops for practice a variety of responses. The method is able to single out situations to which employees is likely to respond better by choosing from a set of principles, than by strict procedures. This would remove the communication obstacles between departments and increase the company's service orientation.

This study may also proceed in another direction, that is, it may include another insurance company from Croatia. This extension would give the opportunity to compare the two companies and determine the effect of service orientation on their financial and market results.

\section{Strengths and weaknesses of the study}

Insurance is a service industry, yet it does not pay enough attention to service orientation. The growing customer's sophistication with respect to the service quality and the growing competition will soon press the industry to improve it.

This study is a contribution to the understanding of insurance industry as a service industry in transitional countries. It has broken new ground - not only in the transitional countries, but also in service marketing worldwide - by investigating this rather neglected segment of service industry. Instead of polling customers' opinion about the service orientation of the Company, this study took new approach to measure service quality and orientation of a company. It confirmed that a company's service orientation largely depended on the employee's perception of it. To ask the employees is as important as to ask the customer because the employee receives internal services and is alone able to assess their quality (Berry et al, 1994). 
Although the method used in the study was hardly used earlier to measure service orientation in other industries but banking, it proved sufficiently flexible and useful.

There are certain limits to this study that should be mentioned. First, this is the only investigation of one insurance company using the $S E R V^{*} O R$ method and as such it cannot be compared to similar studies. Investigations of financial services, dominantly banking, confirmed the reliability of the method, yet specific differences between the insurance and financial service industries may caution us to view the results with some reservation.

Second, as the investigation is limited to one company, it is not able to indicate the influence of service orientation on financial and market results in the industry.

Another limitation is the small sample in departments that counted two to six people. This calls for reservation in interpreting the comparisons between small and big departments. The last limitation of this study is an obvious misconception of the company's service orientation by some employees. It is reasonable to believe that the delayed development of the service market in a postwar transitional country such as Croatia accounts for the lack of understanding of such concepts as service orientation and service-oriented company. 


\section{REFERENCES:}

Berry L. L., Parasuraman A., Zeithaml V. A. (1994)

Improving service quality in America: lessons learned, The Academy of Management Executive, Vol 8. No. 2 1994, p32

Bitner M. J., Booms B. H., Mohr L. A. (1994)

Critical service encounters: the employee's viewpoint, Journal of Marketing, Vol 58. No 4, p95.

Bitner M. J., Booms B. H., Tetreault M. S. (1990)

The service encounter: diagnosing favourable and unfavourable incidents, Journal of Marketing, Vol 54. No 1, p71.

Bowen D. E., Lawler E. E. III (1992)

The empowerment of service workers: what, why, how and when, Sloan Management Review, Vol 33. No 3, p31.

Brown S. W., Fisk R. P., Bitner M. J., (1994)

The Development and Emergence of Services Marketing Thought, International Journal of Industry Management, Vol 5. No. 1 1994, p21

Buttle F., (1996)

SERVQUAL: review, critique, research agenda. (service quality management and management technology), European Journal of Marketing, Vol 30. No 1 1996, p8.

Carson K.P., Cardy R.L., Dobbins G.H. (1992)

Upgrade the employee evaluation process, HRMagazine, Vol 37, No. 11 1992, p88

Cespedes F. V. (1992)

Once more: how do you improve customer service, Business Horizons, Vol 35 No.

2 1992, p52

Champy J. (1997)

Learn to think like your customer, Forbes, Vol 160 No. 13 1997, p96

Cohen H. B. (1994)

Results: the forgotten element of quality programs, SAM Advanced Management Journal, Vol 59 No. 3 1994, p24

Dale B. G. (1994)

A framework for the introduction of a process of quality improvement in retail organizations, International Journal of Retail \& Distribution Management, Vol 22 No. 8 1994, p25

Donnelly J. Jr. (1999)

Beware of negative customer expectations, Bank Marketing, Vol 31 No.8 1999, p60

Drtina R. (1999)

No joke - performance measures can deliver, Strategic Finance, Vol 81 No. 2 1999, p46

European Insurance Bulletin, Deloitte \& Touche, Bruxelles, Winter 1997/1998

Gremler D. D., Bitner M. J., Evans K. R. (1995)

The internal service encounter, Logistics Information Management, Vol 8 No. 4 1995, p28

Hom P., Mokwa M. (1998)

Serv ${ }^{*}$ Or(:) An Organizational Measure of Service Orientation, Journal of Retailing, Vol. 74 No. 4 Fall 1998

Johnson G.K, Roland A. D. (1992)

How to improve quality if you're not in manufacturing, Training, Vol 29 No. 11 1992, p 35

Lovelock C. H. (1999)

Developing marketing strategies for transnational service operations, Journal of Service Marketing, Vol 13 No. 4/5 1999, p278

Lynn M. L., Lytle R. S., Bobek S. (2000), Service Orientation in transitional markets: does it matter?, European Journal of Marketing, vol. 34 No. 3/4, 2000, p279.

Lynn M., Bobek S. (1998)

Service Orientation in Transitional Economies: A Survey of Middle Sized Banks in 
Slovenia versus the United States, The Journal for East European Management Studies, Vol. 3 No. 41998

Lytle R. S., Hom P. W., Mokwa M. P., (1998)

SER ${ }^{*}$ OR: a managerial measure of organizational service orientation, Journal of Retailing, Vol 74. No 4, p455.

Mattson J. (1994)

Using service process models to improve service quality, Managing Service Quality, Vol 4 No. 11994 p47

Welbourne T. M., Johnson D. E., Erez A. (1998)

The role-based performance scale: validity analysis of a theory-based measure, Academy of Management Journal, Vol 41 No. 5 1998, p540

Wengel L. (1998)

Overview: customer satisfaction research, Bank Marketing, Vol 30 No. 9 1998, p16 Wirtz J., Bateson J. E. G. (1999)

Introducing uncertain performance expectations in satisfaction models for service, International Journal of Service Industry Management, Vol 10 No. 1 1999, p82

Wood S. B. (1991)

Using service to outperform the competition, Bank Marketing, Vol 23 No. 9 1991, p37

Zeithaml V. A., Berry L. L., Parasuraman A. (1996)

The behavioral consequences of service quality, Journal of Marketing, Vol 60. No. 2 1996, p31. 
APPENDIX 


\section{Questionnaire}

Drage kolege,

zadovoljstvo korisnika najvažniji je čimbenik za uspjeh našeg poduzeća. Stoga nam je vrlo važno prepoznati koje su potrebe korisnika i koje su naše mogućnosti da im udovoljimo. Naše stvarne mogućnosti možete najbolje procijeniti upravo Vi, zaposlenici Company d.d.

Ovim upitnikom želimo doznati kako Vi procjenjujete kvalitetu usluge koju naša tvrtka pruža našim korisnicima.

Istraživanje će nam pomoći shvatiti kako se stvara usluga u poduzeću i kako ona utječe na učinkovitost i zadovoljstvo Vas, Vaših suradnika kao i naših korisnika. Rezultati ovog ispitivanja upotrijebit će se za poboljšanje kvalitete naše usluge. Molimo da budete što je moguće iskreniji u ocjenjivanju tvrdnji. Ove informacije bit će od male koristi ako vaši odgovori na pitanja ne budu istiniti i točni. Vaši su odgovori strogo povjerljivi.

Zahvaljujemo na suradnji.

\section{Uprava}

\begin{tabular}{|c|c|c|c|c|c|}
\hline Datum: & & & Spol: & Z & M \\
\hline \multicolumn{3}{|c|}{ Ukupan radni staž (godina): } & \multicolumn{2}{|c|}{ Radni staž u Grawe (godina): } & \\
\hline Ured: & Rijeka & Slav. Brod & Split & Zagreb & \\
\hline Odjel: & Obrada & Prodaja & Računovodstvo & Štete & Zajednički \\
\hline Ako prodaja: & Stupanj 1 & Stupanj 2 & Stupanj 3 & Stupanj 4 & \\
\hline Pozicija: & Voditelj & / Uprava & Zaposlenik & Ugovor o radu & \\
\hline
\end{tabular}

\begin{tabular}{|c|c|c|c|c|c|c|}
\hline $\mathbf{1}$ & $\mathbf{2}$ & $\mathbf{3}$ & $\mathbf{4}$ & $\mathbf{5}$ & $\mathbf{6}$ & $\mathbf{7}$ \\
\hline $\begin{array}{c}\text { uopće se NE } \\
\text { slažem }\end{array}$ & $\begin{array}{c}\text { uglavnom se } \\
\text { NE slažem }\end{array}$ & $\begin{array}{c}\text { donekle se NE } \\
\text { slažem }\end{array}$ & $\begin{array}{c}\text { niti se slažem } \\
\text { niti se ne } \\
\text { slažem }\end{array}$ & $\begin{array}{c}\text { donekle se } \\
\text { slažem }\end{array}$ & $\begin{array}{c}\text { uglavnom se } \\
\text { slažem }\end{array}$ & $\begin{array}{c}\text { u potpunosti } \\
\text { se slažem }\end{array}$ \\
\hline
\end{tabular}

\begin{tabular}{|c|l|l|l|l|l|l|l|l|}
\hline 1 & $\begin{array}{l}\text { Zaposlenici skrbe za korisnike kao što bi željeli da se i za njih } \\
\text { skrbi kada su korisnici }\end{array}$ & 1 & 2 & 3 & 4 & 5 & 6 & 7 \\
\hline 2 & Zaposlenici čine posebne napore kako bi zadovoljili korisnike & 1 & 2 & 3 & 4 & 5 & 6 & 7 \\
\hline 3 & $\begin{array}{l}\text { Mi smo primjetno više prijateljskiji i ljubazniji od naših } \\
\text { konkurenata }\end{array}$ & 1 & 2 & 3 & 4 & 5 & 6 & 7 \\
\hline 4 & $\begin{array}{l}\text { Zaposlenici izlaze iz okvira svog djelovanja radi ublažavanja } \\
\text { teškoća korisnika }\end{array}$ & 1 & 2 & 3 & 4 & 5 & 6 & 7 \\
\hline 5 & $\begin{array}{l}\text { Odluke se donose u kontaktu s korisnicima. Drugim riječima, } \\
\text { zaposlenici često donose važne odluke za korisnika bez } \\
\text { traženja odobrenja voditelja/uprave }\end{array}$ & 1 & 2 & 3 & 4 & 5 & 6 & 7 \\
\hline 6 & $\begin{array}{l}\text { Zaposlenici imaju slobodu i ovlast neovisnog djelovanja u cilju } \\
\text { osiguranja vrhunske usluge }\end{array}$ & 1 & 2 & 3 & 4 & 5 & 6 & 7 \\
\hline & $\begin{array}{l}\text { Mi unapređujemo naše mogućnosti pružanja usluga } \\
\text { korištenjem vrhunskih tehnologija }\end{array}$ & 1 & 2 & 3 & 4 & 5 & 6 & 7 \\
\hline 8 & $\begin{array}{l}\text { Tehnologija se koristi za izgradnju i razvoj više razine kvalitete } \\
\text { usluga }\end{array}$ & 1 & 2 & 3 & 4 & 5 & 6 & 7 \\
\hline 9 & $\begin{array}{l}\text { Koristimo vrhunsku tehnologiju radi potpore naporima } \\
\text { zaposlenika koji su u kontaktu s korisnicima }\end{array}$ & 1 & 2 & 3 & 4 & 5 & 6 & 7 \\
\hline & $\begin{array}{l}\text { Mi izlazimo iz djelokruga svog rada kako bi unaprijed spriječili } \\
\text { probleme kod korisnika }\end{array}$ & 1 & 2 & 3 & 4 & 5 & 6 & 7 \\
\hline
\end{tabular}




\begin{tabular}{|c|c|c|c|c|c|c|c|c|}
\hline 11 & $\begin{array}{l}\text { Mi izlazimo iz djelokruga svog rada kako bi unaprijed spriječili } \\
\text { probleme korisnika radje nego reagiramo na probleme kad se } \\
\text { pojave }\end{array}$ & 1 & 2 & 3 & 4 & 5 & 6 & 7 \\
\hline 12 & Mi aktivno slušamo naše korisnike & 1 & 2 & 3 & 4 & 5 & 6 & 7 \\
\hline 13 & Mi imamo odličan sustav rješavanja pritužbi korisnika & 1 & 2 & 3 & 4 & 5 & 6 & 7 \\
\hline 14 & $\begin{array}{l}\text { Oformili smo radne grupe koje unaprijeđuju našu sposobnost } \\
\text { rješavanja problema }\end{array}$ & 1 & 2 & 3 & 4 & 5 & 6 & 7 \\
\hline 15 & $\begin{array}{l}\text { Obavljamo kontakte s korisnicima nakon izvršene usluge kako } \\
\text { bi utvrdili je li naša usluga pravilno izvršena }\end{array}$ & 1 & 2 & 3 & 4 & 5 & 6 & 7 \\
\hline 16 & Mi svakom korisniku dajemo jasno jamstvo za našu uslugu & 1 & 2 & 3 & 4 & 5 & 6 & 7 \\
\hline 17 & $\begin{array}{l}\text { Mi ne čekamo da se korisnici žale, mi koristimo interne } \\
\text { standarde kojima ustanovljavamo pogrešku prije nego primimo } \\
\text { pritužbu korisnika }\end{array}$ & 1 & 2 & 3 & 4 & 5 & 6 & 7 \\
\hline 18 & $\begin{array}{l}\text { Veliki napori se čine kako bi se rezultati istraživanja korisnika } \\
\text { objasnili svim zaposlenicima na razumljiv način }\end{array}$ & 1 & 2 & 3 & 4 & 5 & 6 & 7 \\
\hline 19 & $\begin{array}{l}\text { Svi zaposlenici razumiju sve standarde davanja usluga koji su } \\
\text { uvedeni u svim odjelima }\end{array}$ & 1 & 2 & 3 & 4 & 5 & 6 & 7 \\
\hline 20 & $\begin{array}{l}\text { Razvili smo niz ciljeva koji objedinjuju sve urede i odjele u } \\
\text { ostvarenju svrhe poduzeća }\end{array}$ & 1 & 2 & 3 & 4 & 5 & 6 & 7 \\
\hline 21 & $\begin{array}{l}\text { Mjerenja uspješnosti izvođenja usluge se otvoreno prenose } \\
\text { svim zaposlenicima bez obzira na poziciju i funkciju }\end{array}$ & 1 & 2 & 3 & 4 & 5 & 6 & 7 \\
\hline 22 & $\begin{array}{l}\text { predanost davanju usluge - to nije samo izraz } \\
\text { mo }\end{array}$ & 1 & 2 & 3 & 4 & 5 & 6 & 7 \\
\hline 23 & $\begin{array}{l}\text { Korisnici se gledaju kao mogućnost davanja usluge a ne kao } \\
\text { izvor zarade }\end{array}$ & 1 & 2 & 3 & 4 & 5 & 6 & 7 \\
\hline 24 & $\begin{array}{l}\text { Vjeruje se da, u osnovi, tvrtka postoji kako bi zadovoljila } \\
\text { potrebe svojih korisnika }\end{array}$ & 1 & 2 & 3 & 4 & 5 & 6 & 7 \\
\hline 25 & Voditelji/u & 1 & 2 & 3 & 4 & 5 & 6 & 7 \\
\hline 26 & $\begin{array}{l}\text { Voditelji/uprava redovito provode vrijeme 'na terenu' ili u } \\
\text { kontaktu s korisnicima i zaposlenicima }\end{array}$ & 1 & 2 & 3 & 4 & 5 & 6 & 7 \\
\hline 27 & Voditelji/uprava neprestano mjere kvalitetu usluge & 1 & 2 & 3 & 4 & 5 & 6 & 7 \\
\hline 28 & $\begin{array}{l}\text { Voditelji/uprava pokazuju da brinu o kvaliteti usluge i tako da ju } \\
\text { i sami pružaju }\end{array}$ & 1 & 2 & 3 & 4 & 5 & 6 & 7 \\
\hline 29 & $\begin{array}{l}\text { Voditelji/uprava ne pričaju samo o vrhunskim uslugama, već i } \\
\text { rade na povećavanju mogućnosti zaposlenih za pružanje } \\
\text { vrhunske usluge }\end{array}$ & 1 & 2 & 3 & 4 & 5 & 6 & 7 \\
\hline 30 & $\begin{array}{l}\text { Voditelji/uprava osobno daju smjernice i primjerom pokazuju } \\
\text { kako se stvara kvalitetna usluga }\end{array}$ & 1 & 2 & 3 & 4 & 5 & 6 & 7 \\
\hline 31 & $\begin{array}{l}\text { Voditelji/uprava omogućavaju odlične poticaje i nagrade na } \\
\text { svim razinama za kvalitetnu uslugu, a ne samo za } \\
\text { produktivnost }\end{array}$ & 1 & 2 & 3 & 4 & 5 & 6 & 7 \\
\hline 32 & Ova tvrtka primjetno naglašava vrhunsku uslugu & 1 & 2 & 3 & 4 & 5 & 6 & 7 \\
\hline 33 & $\begin{array}{l}\text { Svaki zaposleni dobiva obuku za povećanje osobnih } \\
\text { sposobnosti radi obavljanja kvalitetne usluge }\end{array}$ & 1 & 2 & 3 & 4 & 5 & 6 & 7 \\
\hline 34 & $\begin{array}{l}\text { Mi trošimo mnogo vremena i napora u vježbama simuliranih } \\
\text { aktivnosti koje nam pomažu dostaviti visoku kvalitetu usluge u } \\
\text { kontaktu s korisnicima }\end{array}$ & 1 & 2 & 3 & 4 & 5 & 6 & 7 \\
\hline 35 & $\begin{array}{l}\text { Tokom vježbi prolazimo kroz različite situacije kako bi } \\
\text { ustanovili i unaprijedili stav prema korisnicima }\end{array}$ & 1 & 2 & 3 & 4 & 5 & 6 & 7 \\
\hline
\end{tabular}


Tables 


\section{TABLE OF CONTENTS}

INTRODUCTION.

Service quality - making the difference and giving impetus to the progress of a service company

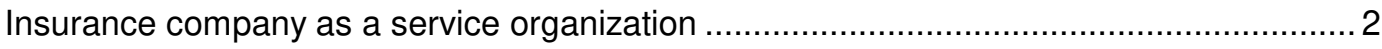

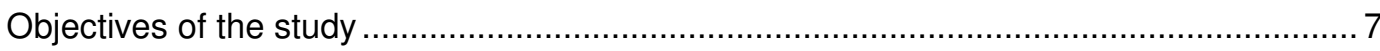

THEORETICAL VIEWS ON SERVICE QUALITY .................................................... 9

Improving the quality of the external customer service experience ................................... 9

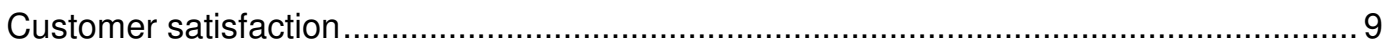

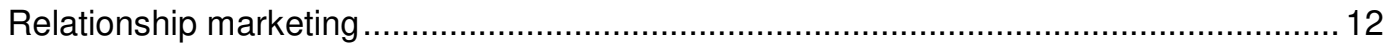

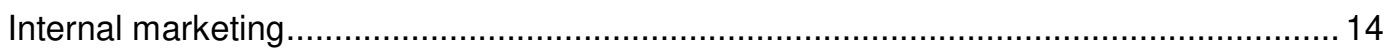

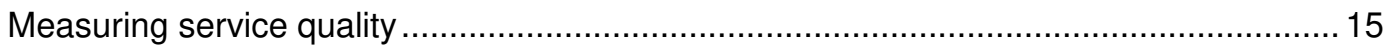

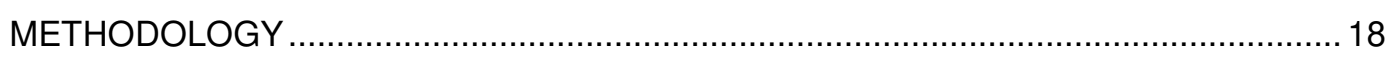

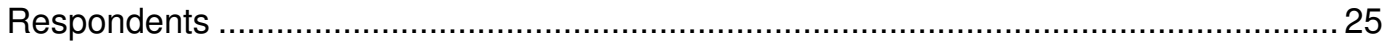

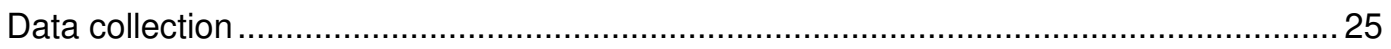

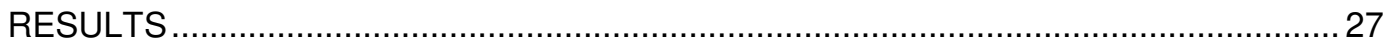

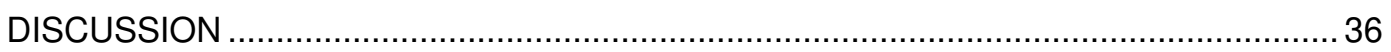

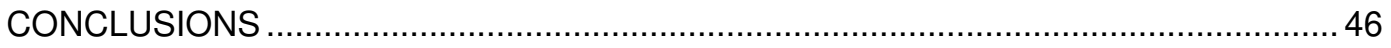

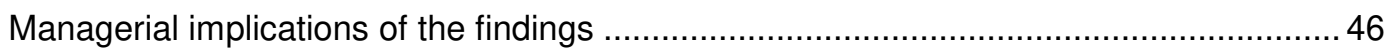

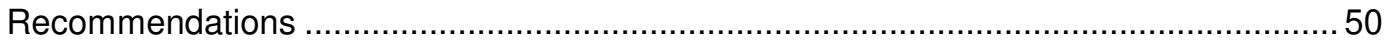

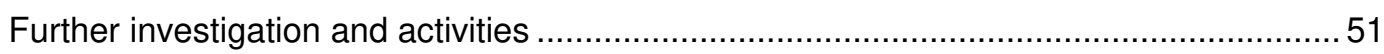

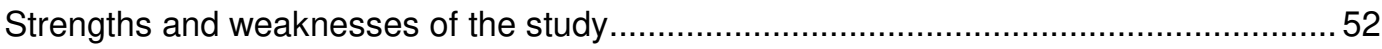

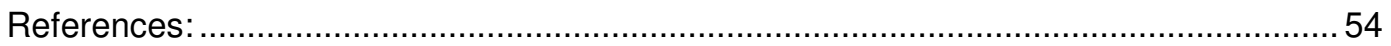

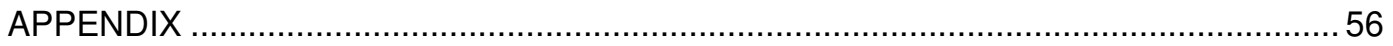

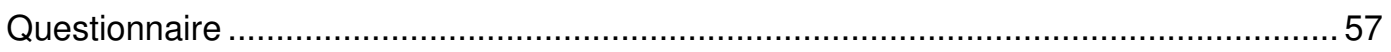

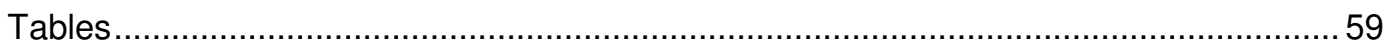

